\title{
Entre recomendações, prescrições e interdições: o aparelhamento moderno nas escolas do Distrito Federal (1939-1942)
}

\section{Among recommendations, prescriptions and prohibitions: the modern apparatus in the schools of the Federal District (1939-1942)}

\author{
Patrícia Coelho da Costa* \\ Ana Chrystina Mignot**
}

\begin{abstract}
RESUMO
Examinar a gestão de Pio Borges no Distrito Federal, no Estado Novo, e, em especial, a reorganização da Seção de Difusão Cultural, responsável pelo rádio e cinema escolar, que surgia como parte da promessa de romper com o legado dos escolanovistas, é o horizonte do presente texto, que pretende interpretar as inflexões sofridas na política de aparelhamento das escolas. Para tanto, privilegiamos jornais, atas, legislação e memórias para interpretar as formas de representação e apropriação destes objetos escolares que envolveram recomendações, prescrições e interdições, entendendo que eles permitem novas compreensões sobre os usos, estratégias e desafios enfrentados por intelectuais e pelo poder público para implementar mudanças.
\end{abstract}

Palavras-chave: Pio Borges. Aparelhamento moderno da educação. Distrito Federal.

* Pontifícia Universidade Católica do Rio de Janeiro. Programa de Pós Graduação em Educação. Rio de Janeiro, Rio de Janeiro. Brasil. E-mail: pcoelho@puc-rio.br. https://orcid. org/0000-0002-2277-2779.

** Universidade do Estado do Rio de Janeiro. Programa de Pós-Graduação em Educação. Rio de Janeiro, Rio de Janeiro, Brasil. E-mail: acmignot@terra.com.br. https://orcid.org/00000001-8944-2021. 


\begin{abstract}
Examining the management of Pio Borges in the Federal District, in the Estado Novo, and, in particular, the reorganization of the Section of Cultural Diffusion, responsible for radio and school cinema, which appeared as part of the promise to break with the legacy of the escolanovistas, is the horizon of the present text that intends to interpret the inflections suffered in the politics of equipping of the schools. In order to do so, we privilege newspapers, minutes, legislation and memories to interpret the forms of representation and appropriation of these school objects, that involved recommendations, prescriptions and prohibitions, understanding that they allow new insights on the uses, strategies and challenges faced by intellectuals and public power to implement changes.
\end{abstract}

Keywords: Pio Borges. Modern education apparatus. Federal District.

\title{
Introdução
}

Ideólogos estadonovistas elegeram o período da administração de Anísio Teixeira como um mal que precisaria ser extirpado e rejeitado. O regime administrativo era considerado inadequado às necessidades nacionais, privilegiando alguns grupos apenas. A Revista Cultura Política divulgava a ideia de que educação escolar praticada antes de 1937 colaborava para a formação de "cidadãos narcísicos, indecisos, irresponsáveis, abstratos, individualistas e egoístas" (SALGADO, 1946, p. 34). Em algumas críticas há referências às propostas desenvolvidas pela Associação Brasileira de Educação (ABE):

Vão cessar enfim as instruções tão perniciosas ao ensino e ao professorado, cuidadosamente elaboradas no terrase da A.B.E., donde tanta novidade tem desabado sobre a instrução municipal. Transformando-o em arranha céu da Casa Garcia na Torre de Bysancio da pedagogia metropolitana dali tem descido as deliberações que os apóstolos da escola socializada difundem com a unção de verdadeiros predestinados. Dali tantos iluminados se espalharam para assombrar os povos, creando os I.P.E, B.C.E., D.P.A.E., S.G.E, S.H.E., escolas experimentaes, orientadoras de ensino e quantas outras coisas possíveis para liquidar o mais solido systema escolar $(\mathrm{O}$ RADICAL, 13/6/1939, p. 3). 
A matéria festejava a nomeação de Pio Borges para Secretário de Educação e Cultura do Distrito Federal no governo do Prefeito Henrique Dodsworth. Tendo sido exonerado a pedido em março de 1942, o engenheiro também atuou como professor de Matemática da Escola Militar de Realengo, exerceu outros cargos públicos, trabalhou na Diretoria de Viação da Prefeitura do Distrito Federal e foi Secretário de Agricultura, Viação e Obras Públicas do Estado do Rio de Janeiro (O RADICAL, 19/6/1941). Compartilhando das críticas ao legado escolanovista quando assumiu a pasta da educação, passou a desenvolver ações com o objetivo de reorganizar o sistema educacional à medida que as experiências do início dos anos 1930 eram por ele consideradas como negativas e prejudiciais à nação, levando-o a afirmar em seu discurso de posse, que

O Estado Novo quer a seção que corrige, edifica ou aprimora. Prometomel-a, sem tergiversações e sem medir sacrifícios por ser esse o novo dever nacional e ainda porque outra forma melhor não existiria para que nos mostrássemos dignos desta elevada investidura e reconhecido aos louvores com que v. ex. captivantemente nos distingue. Seja-nos lícito terminar nossa breve oração adotando e reafirmando o compromisso profundamente nacionalista de Francisco Campos, ex-titular da Secretaria Geral de Educação e Cultura (O RADICAL, 20/6/1939, p. 6).

No período em que esteve à frente da educação praticou a censura de obras literárias nas escolas, tendo elaborado uma lista de livros que deveriam ser retirados das escolas por serem consideradas inadequadas ao público infantil, por não incentivarem o civismo e incitarem o regionalismo, considerado prejudicial à nação. Dentre as obras excluídas das bibliotecas escolares por Pio Borges estavam a versão de Cecília Meireles de Mil e uma noites, Minhas viagens pela Europa de Charles Chaplin, Memórias de Humberto de Campos e obras de Fernando de Azevedo, Anísio Teixeira e Monteiro Lobato (O RADICAL, 30/7/1939). Os volumes, que somavam 4824 obras, foram incinerados (O RADICAL, 8/10/1939). Sua administração contou com verbas extras concedidas pelo prefeito e teve como foco a construção de prédios escolares para acomodar as unidades que funcionavam em espaços alugados, principalmente em áreas rurais; e organizar as aldeias escolares, que eram instituições voltadas para a infância abandonada, em edifícios próprios; bem como o seu aparelhamento.

Ainda na cerimônia de posse, em junho de 1939, o novo secretário destacou que não pretendia realizar reformas. Dirigiria seus esforços no sentido de 
reordenar a pasta nos moldes estabelecidos por leis federais, notadamente no que se refere ao aparelhamento moderno da educação':

Não trazemos a idéa de reformas. A instrução primária do Distrito Federal já obedece as normas por todos aceitas e o gymnasial segue os moldes estabelecidos pelas leis federaes.

Acreditamos que o progresso consistirá no simples aperfeiçoamento do que já possuímos como systema e na maior difusão possível das primeiras letras para o que teremos de nos aparelhar cada vez mais amplamente até que possamos por em prática a alfabetização obrigatória. (O RADICAL, 20/6/1939, p. 6).

O discurso aponta uma preocupação presente desde o início do século $\mathrm{XX}$, quando o rádio, o cinema e o fonógrafo, como adventos da ciência, empolgavam por suas potencialidades em transmitir informação e conhecimento, bem como promover a comunicação e a diversão. Muitas expectativas se formaram em torno desses artefatos técnicos que prometiam transformar a velocidade, o controle e o volume das informações.

Tais perspectivas chamaram atenção de educadores para os usos educativo e escolar dos equipamentos. A presença do rádio, do cinematógrafo e do fonógrafo nas escolas criava demandas específicas, que os diferenciava da apropriação privada que as pessoas faziam destes objetos. As propagandas dos fabricantes dão indícios do que pessoas, com poder aquisitivo que desejavam ter estes aparelhos em suas casas, elegiam como fatores determinantes para a compra: a estética do móvel, a simplicidade do manejo, a capacidade de sintonização das estações. Para apropriação escolar, o custo não só de aquisição, mas de manutenção eram fundamentais, a capacidade de captação dos sinais das estações em diversas localidades, pensando em uma compra coletiva, para uma rede de escolas, o tamanho e a adequação aos diferentes espaços da sala de aula eram fatores determinantes.

1 Francisco Venâncio Filho definiu o aparelhamento moderno da educação como um conjunto de seis instrumentos como brinquedos, rádio, cinema, fonógrafo, viagens e excursões, museus e livros considerados "fatores no sentido próprio do termo multiplicadores, porque multiplicam de fato em extensão em intensidade" (1941, p. 14). O autor destaca a relação entre a escola e a ciência no início do século XX, em especial a apropriação da radiofonia, da cinematografia e do fonógrafo para ampliação de sua obra ingente (p. 14). 
Seguindo as pistas dos estudos de Escolano Benito (2000) quando destacam que as análises sobre o espaço escolar e seus objetos contribuem para superar os silêncios da historiografia da educação, compreendemos que investigar os usos escolares do rádio e do cinema pode colaborar para a compreensão história da escola na perspectiva anunciada por Hernández Diaz (2002), quando reivindica linhas de interpretação mais complexas e a "partir de las quales lo material y los objetos dejan de ser vanos, insustanciales, para pasar a ocupar posiciones de mayor protagonismo en la escala de la reflexión" (p. 231). Apesar de pouco ter restado sobre o passado deste mundo da imagem e do som, seja pela falta de interesse das produtoras e emissoras na conservação de fitas e discos a longo prazo do seu acervo, seja pela reutilização dos materiais, que eram muito caros, ou por acidentes, como incêndios, que os destruíram, nos debruçamos sobre jornais, atas, legislação e memórias para interpretar as formas de representação e apropriação de objetos escolares que envolveram recomendações, prescrições e interdições, entendendo que eles permitem novas compreensões sobre as práticas, estratégias e desafios enfrentados por intelectuais e pelo poder público para implementar mudanças.

Ao elegermos a gestão de Pio Borges, no Distrito Federal, e, em especial, a reorganização da Seção de Difusão Cultural, responsável pelo rádio e cinema escolar, que surgia como parte da promessa de romper com o legado dos escolanovistas, pretendemos interpretar as inflexões sofridas na política de aparelhamento das escolas, na perspectiva de Ingold (2012), quando destaca que a tecnologia não pode ser compreendida separada de suas relações sociais, assim como sua concepção não pode ser dissociada dos seus usos. Acreditamos, assim, que será possível pensar as diferentes formas de apropriação escolar do aparelhamento moderno da educação, ocorrido no Distrito Federal praticamente no espaço de uma década, a partir das diferentes políticas educacionais e culturais desenvolvidas no período.

\section{Rádio e cinema: debates e iniciativas dos educadores escolanovistas}

A proposta do rádio e do cinema escolar apresentava aos educadores escolanovistas, reunidos na Associação Brasileira de Educação (ABE), bem como aos reformadores do Distrito Federal a potencialidade que os meios de comunicação "representam em países de larga área territorial, como o Brasil, um papel de marcado relevo, porque permitem pôr a serviço da educação, instrumentos de longo alcance, possibilitando uma aceleração crescente na obra que é o grande 
compromisso da hora atual" (VENÂNCIO FILHO, 1941, p. 14). A rigor, na década de 1920, intelectuais como Roquette-Pinto, Francisco Venâncio Filho, Edgar Sussekind de Mendonça, Miguel Ozório de Almeida, Jonathas Serrano e Dulcídio Pereira acreditavam que o rádio e o cinema seriam capazes de promover a integração nacional por meio da cultura (COELHO, 2016). Vários estudiosos foram responsáveis pela implementação da radiofonia no Brasil e também atuaram ativamente em experiências com a cinematografia.

No caso da radiofonia, o Decreto 21.111, de $1^{\circ}$ de março de 1932, que regulamentou o uso do rádio em nosso país, significou uma vitória apenas parcial para os defensores da radiocultura. Apesar de estabelecer a finalidade educacional da radiofonia, a regulamentação era falha, pois não definia os parâmetros que caracterizariam uma programação como educativa. Oficialmente, estipulou-se apenas que o Ministério da Educação e da Saúde conduziria a normatização do assunto e daria orientação às emissoras. Por outro lado, a legislação impôs um prazo de dois anos para que as estações remodelassem sua aparelhagem e se tornassem mais potentes. As sociedades de rádio tinham um orçamento deficitário e dificilmente disporiam de recursos financeiros para cumprir estas exigências. Os educadores sentiam que a radiocultura estava seriamente ameaçada, vez que a lei previa a cassação dos direitos de transmissão das emissoras que não se adequassem aos novos padrões técnicos. Os intelectuais voltaram seus esforços para a defesa da rádio escola e para criação de parâmetros de classificação para os programas educacionais (COELHO, 2016).

Edgard Roquette-Pinto, fundador da Rádio Sociedade do Rio de Janeiro (PRA2), como lembrou Fernando Segismundo (1994), que "tão densos serviços prestou à educação e à cultura nacionais", por não querer "sujeitar-se aos ditames do mercado financeiro, (...) doou a emissora ao Ministério da Educação e Saúde na administração de Gustavo Capanema" (p. 200) que, ao longo do período, agregou diferentes tendências:

Foi o ministério dos modernistas, dos Pioneiros da Escola Nova, de músicos e poetas. Mas foi também o ministério que perseguiu os comunistas, que fechou a Universidade do Distrito Federal (UDF), de vida ativa e curta, expressão dos setores liberais da intelectualidade do Rio de Janeiro (1935-1939). Foi, ainda, o ministério que apoiou a política nacionalizante de repressão às escolas dos núcleos estrangeiros nacionalizantes (BOMENY, 1999, p. 137).

Roquette-Pinto também organizou, em 1910, o primeiro acervo de filmes, 
instalado no Museu Nacional, a partir das coleções científicas da Pathé e juntamente com Jonathas Serrano, criou um aparelho destinado a projeções fixas para uso escolar, denominado "lanterna escolar" que, segundo Souza (2016), refletia o entendimento de que "as transações comerciais mobilizariam parte das políticas educacionais o que demandaria investimentos significativos por parte do poder público para difusão e manutenção deste objeto escolar" (p. 117). Em 1936, participou da criação do Instituto de Cinema Educativo (INCE), ligado ao Ministério da Educação. Fernando Segismundo, ao lembrar da presença de Francisco Venâncio Filho neste instituto, assinalou que tal instituto, bem como o Serviço de Radiodifusão Educativa (SRE) funcionavam no mesmo prédio, na Praça da República e as "duas repartições confundiam-se nas finalidades por terem em princípio um só diretor: Edgar Roquette-Pinto, cuja solicitude levou o ministro Capanema a instituí-los e entregar-lhes.” Registrou ainda a composição da equipe:

A parte técnica de ambas as casas competia a especialistas do porte de Labre Junior e Humberto Mauro, coordenadores de equipes esforçadas. A lavra artística, científica e educativa tocava a numerosos colaboradores de fora e à prata interna - técnicos de educação, professores, jornalistas e literatos. Dentre tantos, assinalavam-se Fernando Tude de Souza, a quem Roquette acabou por entregar o comando da rádio, e Pedro Gouveia Filho, que substituiu o próprio Roquette, a pedido deste, no cinema. A esses auxiliavam René Cavé, Paschoal Lemme, Beatriz R.P. Bojunga, Edgar Sussekind de Mendonça, Aidano de Couto Ferraz, Otávia Régia Konder e muitos mais homens e mulheres que faziam daquelas entidades seus segundos lares (SEGISMUNDO, 1994, p. 203).

\section{Propostas em discussão na Associação Brasileira de Educação}

No âmbito da Associação Brasileira de Educação ${ }^{2}$ - retratada em O Radical, por ocasião da posse de Pio Borges, como a entidade que divulgava instruções tão perniciosas ao ensino e ao professorado -, a compreensão de que o rádio e o cinema deveriam ser utilizados na escola ganhava espaço tanto no Conselho

2 Sobre a ABE consultar: CARVALHO, Marta. Molde nacional e fôrma cívica: higiene, moral e trabalho. Bragança Paulista, EDUSF, 1998. 
Diretor quanto na Seção de Cooperação da Família e na Seção de Ensino Técnico e Superior, deixando entrever que para os intelectuais ali reunidos

$\mathrm{Na}$ forma da educação escolar, os objetos enunciam forças políticas, históricas, culturais e sociais e a circulação destes artefatos interfere e/ ou representa um modelo de educação. A modernidade expressa pelas instituições e, neste caso específico pelas instituições escolares, assume um símbolo de futuro e progresso (SOUZA, 2016, p. 106).

Desde o ano de 1927, os debates sobre o rádio se intensificaram no Conselho Diretor da ABE com Ferdinando Labouriau, Amoroso Costa e Mario de Brito, na Presidência, e outros sócios efetivos da Rádio Sociedade do Rio de Janeiro (PRA2) e da Academia Brasileira de Ciências (ABC) como, por exemplo, Francisco Venâncio Filho, Othon Leonardos, Álvaro Ozório de Almeida e Dulcídio Pereira. As discussões realizadas nas sessões do Conselho Diretor sobre radiofonia, com a presença de diretores da emissora, são reveladoras, na medida que demonstram a forma como essas duas entidades interagiam. Nesse período, o mesmo grupo desenvolvia uma atuação consistente no Partido Democrático do Distrito Federal, intensificando o movimento de reestruturação de nossas instituições políticas e culturais, como nos lembra Carvalho (1998). O rádio era um veículo fundamental a esse processo, que exigia a influência intelectual da elite sobre o povo.

Na reunião de $1^{\circ}$ de abril, Dulcídio Pereira, chefe da Seção de Broadcasting da PRA2, e Roquette-Pinto, diretor da PRA2, lançam a proposta de fusão da rádio com a $\mathrm{ABE}$ ou um acordo de colaboração, uma vez que a Rádio Sociedade tem por fim a propagação da arte, da sciencia, tem personalidade jurídica, tem patrimônio e varios compromissos (ATA DE REUNIÃO ABE, 1926). Fica a ideia de que as instituições poderiam se complementar, pois tinham perspectivas semelhantes. Como veículo de comunicação, a emissora poderia dispor de várias opções de divulgação da causa educacional e cultural. Venceriam a distância e o isolamento, tendo amplitude nacional. Fica acertada a constituição de uma comissão para assuntos de radiodifusão composta por Ferdinando Labouriau, Barbosa de Oliveira e Fernando de Magalhães (COELHO, 2016).

Na semana seguinte, maiores detalhes da proposta de fusão seriam expostos: a ABE criaria uma seção de Radiocultura, que seria entregue a Radio Sociedade. Por sua vez, a PRA2 daria uma subvenção à ABE como forma de financiar o rádio educativo. Álvaro Ozório de Almeida assumiu a Presidência da Seção de Radiocultura da ABE. 
Em uma das primeiras ações da seção de Radiocultura, define-se a opção pela transmissão das palestras científicas promovidas pela Seção de Ensino Technico e Superior. Em julho, a seção lança o programa Pilulas scientificas, sob a responsabilidade de Ferdinando Labouriau e com o propósito de vulgarização científica. Em linhas gerais, a proposta de integração entre a PRA2 e a ABE indica o ideal compartilhado pelas duas associações: a reorganização da sociedade em torno da cultura e da ciência.

O desenvolvimento da radiofonia e da cinematografia nas escolas assegurava que o Estado financiasse a produção de filmes e a criação e manutenção de emissoras de rádio voltadas aos fins escolares. A sobrevivência de projetos idealizados por Francisco Venâncio Filho, que integrava com Edgar Roquette-Pinto, Jonathas Serrano, Dulcídio Pereira, Lourenço Filho, se deu em decorrência de uma rede de sociabilidade responsável pelo desenvolvimento da radiofonia e da cinematografia escolares em nosso país, em um projeto no qual a propaganda comercial era por eles rejeitada, na medida em que defendiam a tese de que estes meios de educação deveriam estar voltados para fins exclusivamente educativos e culturais. Para atingir tal objetivo, justificavam a prática da censura para que crianças e jovens não tivessem contato com conteúdos moralmente inadequados e de baixo teor cultural (COELHO; PAULILO, 2015). Acreditavam que a propaganda era nociva, pois era um desperdício de tempo, à medida que desvirtuava a atenção dos receptores para questões fúteis. Na escola estes aparelhos aprimorariam métodos, supririam a carência da formação de professores e, por fim, contribuiriam para criar laços nacionais em torno da cultura.

A compreensão de que estes recursos deveriam ser utilizados na escola também estava nítida para as educadoras reunidas na Seção de Cooperação da Família ${ }^{3}$, que procuravam atuar para além da esfera escolar, ampliando seu raio de ação, recomendando, prescrevendo ou interditando os usos do rádio e do cinema na sociedade. Em nome da defesa à infância, condenavam, por exemplo, a transmissão pelo rádio de sessões do júri por acreditarem que incitavam ao desvario $e$ ao crime, opinião contestada pelo juiz Magarinos Torres, que defendia proposta contrária por entender que a sociedade tinha o direito de fiscalizar os jurados e precisava conhecer a justificação dos crimes e o funcionamento da justiça ${ }^{4}$.

3 Sobre a Seção de Cooperação da Família, da ABE, consultar: MIGNOT, Ana Chrystina Venancio. Baú de memórias, bastidores de histórias: o legado pioneiro de Armanda Álvaro Alberto. Bragança Paulista, EDUSF, 2002.

4 Posição esta aplaudida por Cecília Meireles que acreditava ser esta uma posição mais avançada do que a da associação, na medida em que apresentando, publicamente atos de justiça, quebrava crimes de segredo, apresentando atos de justiça, constituindo-se, assim, em meio para eliminar a justicinha-fraude (...) sustentada precisamente pela sombra em que se desenvolve, e pelo restrito auditório que lhe assiste, débil para qualquer protesto (DIÁRIO DE NOTÍCIAS, 13/07/1930, p. 5). 
Do mesmo modo, o cinema - considerado por Afrânio Peixoto como "a maior das invenções da civilização humana" (VENÂNCIO FILHO, 1941, p. 42) - não escapava das inquietações moralizadoras da Seção de Cooperação da Família, que nas reuniões quinzenais se incumbia de elaborar listas com livros e filmes adequados à infância:

Uma comissão composta por D. Maria Amália Castro e Silva e professores Mrs Andrews e Edgard Sussekind de Mendonça está promovendo sessões infantis em vários cinemas desta capital, havendo a Associação dirigida aos exhibidores uma circular em que se offerece a examinar o valor educativo dos filmes destinados a taes sessões, podendo declarar a sua aprovação e contar com sua propaganda junto aos directores dos colégios para a garantia de assistência. Pretende também a Commissão fazer um recenseamento dos filmes apropriados que se encontrem em stock e possam ser re-exhibidos systematicamente (BOLETIM DAABE, 09/1925, p. 7).

No período compreendido entre os anos 1920 e 1940 a Secretaria de Instrução do Distrito Federal desenvolveu diferentes estratégias de apropriação do rádio, do cinema e do fonógrafo, como se pode ver no empenho dos reformadores do ensino - Fernando de Azevedo e Anísio Teixeira - para traduzir na composição material das escolas a ideia de modernização da educação (SOUZA, 2016), o que os levou a desenvolver estratégias de apropriação dos aparelhos.

\section{Iniciativas da Diretoria de Instrução Pública do Distrito Federal}

Durante a gestão de Fernando de Azevedo, a necessidade de instalação de salas destinadas ao cinema e ao rádio, devidamente aparelhadas, visavam à "irradiação diária para as escolas e para o público de hinos e canções escolares, da hora oficial, do boletim de atos e instruções da diretoria geral, de todos os interesses do ensino, lições e sessões artísticas de caráter educativo" (AZEVEDO, 1976, p. 209), como se pode ver no artigo 633 do Decreto Municipal 2.940/1928: "as escolas de ensino primário normal, doméstico e profissional, quando funcionarem em edifícios próprios, terão salas destinadas à instalação de aparelhos de projeção fixa e animada para fins meramente educativos, bem como a instalação de aparelhos de rádio telefonia e alto falantes" (DISTRITO FEDERAL, 1928). 
As estratégias de apropriação derivavam do interesse dos educadores pelo aparelhamento moderno, o que pode ser dimensionado pela importância que o tema mereceu na "Página de Educação" dirigida por Cecília Meireles, no Diário de Notícias, entre 1930 e $1933^{5}$, na qual algumas matérias e artigos sobre a utilização da radiodifusão, projeções, cinematógrafo e cinema na educação evidenciam as preocupações existentes para que a escola incorporasse os avanços técnicos, científicos e culturais. Experiências e estudos realizados em outros países - Inglaterra, Espanha, França, Alemanha, Áustria, Itália e Japão, por exemplo - eram amplamente divulgados numa tentativa de convencer o poder público e a opinião pública da importância de sua utilização, bem como legitimar as iniciativas em curso. Tomados como modelos, deveriam ser seguidos, imitados, implementados.

No campo da radiotelefonia, Andrew Blackmore, em uma matéria exclusiva, chamou a atenção para o uso educativo do rádio nas escolas inglesas, onde a BBC tinha um forte papel não só transmitindo conferências de caráter técnico e científico, mas também apoiando a formação de grupos locais que se reuniam para ouvir conferências especializadas (DIÁRIO DE NOTÍCIAS, 13/11/1930, p. 14). Na Inglaterra, onde havia o monopólio do Estado, o que era visto como responsável por interessantes resultados, o uso do rádio na escola previa a elaboração de brochuras preparadas por professores para estimular o ensino de línguas, história, música, literatura, história natural, geografia e economia rural.

Da Espanha chegavam notícias do emprego de novos recursos e técnicas pedagógicas em substituição às práticas expositivas demasiadamente dependentes dos manuais escolares. Longe de diminuírem o esforço dos professores, o uso do cinema na escola exigia maior preparo das aulas o que envolvia além do aperfeiçoamento pedagógico, aperfeiçoamento técnico: “estudará o aparelho, posto à sua disposição, aprenderá a colocar a película, a verificar as conexões elétricas, a por o aparelho em disposição de funcionar, a lubrificá-lo e limpar os acessórios. Converter-se-á assim facilmente em um bom operador" (COLLETE, DIÁRIO DE NOTÍCIAS, 8/3/1931, p. 7).

Atílio Vivacqua - que lançara mão da projeção animada e da projeção fixa na reforma do ensino do Espírito Santo, por acreditar na supremacia da lição da imagem sobre a auditiva, na medida em que era mais forte, duradoura, satisfazia princípios da psicologia infantil e proporcionava maior rendimento didático apontava um estudo nos Estados Unidos que comprovava tal superioridade, sobretudo em economia de tempo:

5 Sobre o trabalho jornalístico de Cecília Meireles na Página de Educação do Diário de Notícias, consultar NEVES, Margarida de Souza. LÔBO, Yolanda Lima e MIGNOT, Ana Chrystina Venancio (Orgs). Cecília Meireles: a poética da educação. Rio de Janeiro: Editora PUC-Rio; Loyola, 2001. 
Num filme podemos ver, em alguns minutos, o ciclo vital de uma semente, da germinação à frutescência, o mundo dos micróbios e dos astros, os segredos do dinamismo e as maravilhas de mecânica moderna, desertos, florestas, oceanos e civilizações (DIÁRIO DE NOTÍCIAS, 23/10/1930, p. 6).

Continuando a enumerar o "formidável passo no terreno da economia pedagógica, apreciada sob o ponto de vista da menor duração do ensino", Atílio Vivácqua (DIÁRIO DE NOTÍCIAS, 23/10/1930, p. 6) citava as admiráveis experiências da rádio cinematografia na França, Alemanha e Áustria, destacando o Instituto Internacional de Cinematografia, em Roma, custeado pelo governo italiano, sob a direção da Liga das Nações. A criação deste instituto, a seu ver, definia a importância do cinema educativo para os Estados modernos, não só como elemento de educação popular, mas de cooperação entre povos, como destacara Mussolini, em novembro de 1928, na inauguração, quando disse que o cinema, falando uma língua universal, é superior ao livro e ao jornal.

Outros estudos desenvolvidos no Japão comprovavam que crianças, após impressões deixadas por determinadas projeções, permaneciam muito tempo desatentas às lições, mergulhadas em verdadeiro torpor. Apresentavam fadiga e depressão. Os testes evidenciavam que após os doze anos a atenção não sofria alteração. Aconselhava-se, após minucioso inquérito, promovido pelo Comitê de Cultura Física e de Saúde:

A fadiga pode, então, começar por se manifestar ao fim de 18 a 20 minutos. Os pequeninos nevropatas, predispostos ao desequilíbrio nervoso, podem ser afetados por crises, convulsões, terrores noturnos e fobias diversas. Em suma, o 'comitê' especial de médicos japoneses concluiu que é preferível conduzir as crianças ao cinematógrafo somente depois de treze anos de idade (DIÁRIO DE NOTÍCIAS, 11/10/1930, p. 4).

Alicerçado em experiências desenvolvidas no país e no exterior, em 1934, Anísio Teixeira ${ }^{6}$, Diretor da Instrução Pública do Distrito Federal, inaugurou a Rádio Escola Municipal (PRD5), dirigida por Edgar Roquette-Pinto. A estação assegurava a proposta de radiocultura. Tinha uma programação composta por páginas literárias e musicais, assim como um jornal dirigido aos professores,

6 Sobre Anísio Teixeira no Distrito Federal ver estudo de NUNES, Clarice. Anísio Teixeira: poesia da ação. Bragança Paulista, EDUSF, 2000. 
para que estes conhecessem os estudos desenvolvidos pelo Instituto de Pesquisas Educacionais (IPE) e lições para que estudantes complementassem o conhecimento adquirido nas escolas. Houve a contratação de radioeducadores como Ilka Labarthe, Marina de Pádua, Ariosto Espinheira e Genolino Amado. Entre os programas elaborados pelo casting da PRD5 é possível citar $O$ tapete mágico da Tia Lúcia, de Ilka Laberth, A biblioteca do ar, de Genolino Amado e o Jornal dos Professores, de Ariosto Espinheira. Assim como outras iniciativas de sua gestão, esta também sofreria abandono e críticas, pois como lembra Paschoal Lemme, em suas memórias, o "pique de progresso" vivido na administração de Anísio Teixeira entrou em decadência quando "as forças retrógradas assumiram a direção dos serviços de educação do País", deixando para trás o tempo em que se investiu em escolas, na formação de professores e no aparelhamento moderno da educação:

O Instituto de Educação tornou-se um estabelecimento modelar de formação de professores primários do Distrito Federal e, mais tarde, também de técnicos e orientadores de ensino. Em seus cursos formou-se toda uma geração de educadores do mais alto nível, que recebiam lições dos mestres mais ilustres que por ali passaram e que dispunham de uma aparelhagem e de instalações as mais modernas. [...]

Outras iniciativas relacionadas com o enriquecimento do ensino primário foram adotadas: as escolas experimentais ensaiavam a prática de métodos e técnicas modernas de ensino tais como o 'método de projetos', o 'sistema Platoon', em vista de uma possível generalização futura. A seção de Museus e Radiodifusão, entregue à competência de Roquete-Pinto, fundou uma radioescola, que passou a transmitir programas diários divididos em 3 partes: hora infantil, jornal dos professores e suplemento musical. Uma divisão de bibliotecas e cinema educativo pôs ao alcance do magistério carioca o livro e o filme, para seu aperfeiçoamento permanente e como meios auxiliares de ensino (LEMME, 1988, p. 139).

A rede de sociabilidade construída em torno da defesa da presença do rádio, do cinematógrafo e do fonógrafo nas escolas viveria uma nova fase na administração de Pio Borges, revelando concepções educacionais bem diferentes. Neste processo contínuo estão as discussões sobre os desafios da implementação do aparelhamento como objetos escolares, que envolviam aspectos como o custo, as técnicas pedagógicas, a adequação do conteúdo, a produção de programas, a censura e a formação dos professores. 


\section{Pio Borges e o aparelhamento escolar na reorganização do ensino municipal}

O caráter de mudanças consideradas adequadas à Seção de Difusão Cultural pode ser dimensionado a partir da leitura da reportagem intitulada $O$ homem que tem uma braza nas mãos. Nesta matéria publicada no dia 8 de março de 1940, a palestra do professor Astrogildo Pereira, diretor do cinema educativo no Instituto de Educação, é definida como espetáculo ridículo:

Chega o Major Chaves, como um convidado de honra, nada menos do que um general do Exército. Sobe ao tablado um indivíduo de aspecto caturra, com óculos incríveis acavalados no narizame. A exibição theorica deixou todos os presentes espantados. Decorou o homenzinho uma phrases dificieis, como que obumbrar o brilho da assistência. Fala em sociologia, para declarar que os problemas humanos não são aritméticos, mas equacionaes, e que tudo estará resolvido no dia em que esses problemas forem resolvidos por equações geométricas.

O orador então vae as demonstrações. Não vamos nos referir a passagem de films mudos e falados projetados na parede, não chegaremos mesmo ao ponto em que o orador dá a conhecer sua invenção que consiste mais ou menos, no seguinte: em vez de estar a falar o professor durante todo o tempo da exibição dos films - entende-se que são films educativos o orador quis arranjar que o espírito encontre repouso e divertimento nas lições. Que processo é este? Apanha uma vitrola põe-lhe um disco para entremear a recitação do roteiro (roteiro são as lições escritas do que está projetado na tela) com uma marchinha carnavalesca! Todos se olham, formulando-se a mesma pergunta: Mas esse sujeito é louco? (O RADICAL, 8/3/1940, p. 2).

Tal crítica parece ter inspirado a reorganização na Diretoria de Difusão Cultural, que se iniciou com a concentração dos serviços no Edifício Andorinha. Em junho de 1940, a Rádio Escola Municipal (PRD5) se transferiu para o prédio na Esplanada do Castelo e mudou de nome, passou a se chamar Rádio Transmissora da Prefeitura, e, segundo Ribeiro (2009), foi vinculada ao Serviço de Divulgação da Prefeitura. Um ano depois foi inaugurada a Discoteca Pública do Distrito Federal no mesmo endereço. A proximidade do gabinete de 
Pio Borges, localizado apenas alguns andares acima é um indício do controle exercido sob os funcionários destas seções. As administrações anteriores eram acusadas de conceder excesso de liberdade aos funcionários, o que acabava desvirtuando o uso dos meios de comunicação para outros fins que não fosse o de educar as massas.

A proximidade dos setores responsáveis pelo desenvolvimento da radiofonia, do fonógrafo e do cinema educativos também retrata o esforço pela integração destes recursos didáticos. A ideia era de que, ao produzir programas radiofônicos, os produtores pudessem contar com o material da Discoteca Pública, que, por sua vez, disponibilizava programas radiofônicos gravados em discos em suas mesas para audição. A parte administrativa do cinema educativo também se encontrava no Andorinha, estando o estúdio de gravação e depósito de filmes na rua do Passeio. Para os diretores de escola e professores que quisessem conhecer as dependências ou fazer cursos, a curta distância que separava os setores também era importante.

Ao iniciar sua administração, Pio Borges nomeou o Major Alexandre José Gomes da Silva Chaves para promover a reorganização do setor:

A educação municipal entra assim em uma nova phase e nós como o público em geral, aguardamos que Ella seja realmente útil aos interesses de nossa população escolar, isto é que se norteie por outros caminhos que não os trilhados pelos administradores que tanto prejudicaram o ensino e o magistério municipal (O RADICAL, 22/6/1939, p. 3).

Em 1940, inicia o processo de regulamentação dos usos educacionais dos meios de comunicação no Distrito Federal. Para além das normas já estabelecidas pelo Ministério de Educação e Saúde Pública, o secretário Pio Borges determina regras que devem ser seguidas pelas escolas e pela Radio Escola Municipal. Os temas e horários dos cursos passaram a ser regulados pelo diretor do Departamento de Difusão Cultural. Ficaria reservada uma parte da programação para irradiação do Departamento de Educação Nacionalista. As aulas irradiadas deveriam obrigatoriamente ouvidas nas escolas públicas e particulares. Para organizar a recepção escolar, os cursos foram divididos em duas seções: os sistematizados dirigidos à comunidade escolar e os de oportunidades, voltados ao público em geral. No primeiro tipo visavam à educação da criança ao jovem: 
São todos eles complementos dos cursos dados nas sedes das escolas, onde a determinadas horas, o aluno liga o aparelho de rádio, aprendendo a manejá-lo e a conhecer-lhe as peças e a ter noções da aplicação moderna da eletricidade. E toda classe ouve então o que lhe tem a dizer os professores especializados, cuja voz parte do estúdio central (GAZETA DE NOTÍCIAS, 15/8/1941, p. 4).

O setor de cinema educativo deveria distribuir os filmes nas escolas sob forma de empréstimo. A seção também seria encarregada de produzir roteiros pedagógicos para os professores. A participação do mestre era considerada fundamental: ao longo das projeções deveriam ser feitos comentários de acordo com o nível da turma. Neste aspecto, é possível identificar a influência de Edgar Roquette-Pinto e Francisco Venâncio Filho. Para estes pioneiros da cinematografia educativa no Brasil o verdadeiro cinema deve constituir não um descanso para o professor e sim um novo encargo acrescido aos seus deveres.

Um aspecto importante no processo de aparelhamento das escolas foi a ampliação do número de equipamentos. De acordo com Ribeiro (2009),

Pio Borges assinou mais três contratos em fevereiro de 1940, com a mesma finalidade. Em um deles estipula a compra de amplificadores, microfones e pick-ups para gravações (iniciando então o programa de gravações da discoteca da emissora). Outro determina a compra de altofalantes, equipamento para reprodução de discos e um mixer. O terceiro desses contratos estipula a aquisição, entre outros equipamentos, de "40 sub-estações em caixas especiais (tipo escolar) [...] fabricados para transmissões ou recepções, com dispositivo que permite a qualquer subestação se comunicar com a estação mestre." Essas estações deveriam ser instaladas no Instituto de Educação (p. 76).

Assim, foi organizada a oficina da Radiodifusão, que montava equipamentos e prestava assistência técnica para rádios e cinematógrafos. Neste sentido, é destacada a montagem de um tipo de rádio denominado R.E., que passou a ser usado nas escolas do Distrito Federal:

Este tipo de aparelho é usado nas escolas municipais, de vez que a pedagogia moderna tem no rádio uma das mais eficientes técnicas auxiliares. $\mathrm{O}$ estudo deste tipo de receptor foi um dos problemas resolvidos com 
felicidade pelos técnicos do Serviço de Divulgação: economia e fidelidade na recepção (A MANHÃ, 20/5/1942, p. 3).

A produção de programas e filmes visava a atender à proposta de socialização de valores nacionalistas estabelecida pelo Estado Novo. Após a reorganização da Rádio Difusora da Prefeitura, um dos primeiros lançamentos foi o Curso de Divulgação Nacionalista destinado à infância, cujo tema da primeira irradiação foi "a personalidade do Presidente Vargas" (A MANHÃ, 16/4/1941, p. 6, grifos nossos). Na parte musical era anunciado o programa Música Heróica Brasileira com "dobrados e marchas de nossas forças militares, gravados com a finalidade de substituir nas estações transmissoras as marchas guerreiras de países estrangeiros" (GAZETA DE NOTÍCIAS, 6/1/1942, p. 4).

Uma estratégia adotada para divulgar as datas cívicas e comemorativas muito valorizadas no contexto estadonovista era a integração da Rádio Escola, da filmoteca e da discoteca pública. Na Semana da Criança de 1943, a Radio Difusora da Prefeitura preparou audições especiais de músicas infantis gravadas pela Discoteca Pública e a filmoteca educativa selecionou os seguintes títulos para projeção nas escolas e no Clube Municipal: “Orquestra Sinfônica Infantil, Dilema de Andy Hardy, O campeão olímpico, de Walt Disney, Uma aventura no jardim zoológico, Como nadar, Como esquiar, desenhos de Walt Disney" (GAZETA DE NOTÍCIAS, 9/10/1943, p. 5). A participação das escolas era cobrada neste tipo de programação. Na Semana da Pátria, ainda em 1941, foi veiculado o seguinte anúncio:

Aos alunos ouvintes dos diferentes programas serão solicitados trabalhos que reúnam os assuntos irradiados, sendo esses trabalhos expostos, na semana seguinte em local previamente anunciado. Aos trabalhos classificados serão conferidos prêmios. As escolas que não possuem aparelho radio recptores poderão solicitar pelo telefone 421236 (Radio Escola) os questionários formulados no fim das aulas para concorrerem a exposição e aos prêmios (A NOITE, 2/9/1941, p. 5).

\section{Cursos para os usos do aparelhamento moderno nas escolas}

Para que o aparelhamento moderno fosse implementado nas escolas era necessário que a Prefeitura investisse em cursos para os professores. No regi- 
mento, que passou a regulamentar a rádio escola no governo de Pio Borges, estava previsto a organização de cursos regulares oferecidos por radioeducadores, com o objetivo "de fomentar os elementos práticos e teóricos ao magistério que colabora com as atividades do rádio na escola" (A NOITE, 29/08/1941, p. 2)

O primeiro curso de radiofonia escolar, visando à aplicação do aparelhamento moderno na administração de Pio Borges, contou com a participação dos radioeducadores pioneiros da Rádio Escola Municipal (PRD5), a saber, Ariosto Espinheira e Genolino Amado, e do técnico Labre Júnior da Rádio Ministério da Educação (COELHO, 2016). O curso foi ministrado nas dependências do Edifício Andorinha. O programa foi dividido em duas partes: teórica e prática. $\mathrm{Na}$ primeira, abordaria o histórico da radiodifusão, os elementos do estúdio e seus problemas técnicos, como organizar um programa, a discoteca e sua importância, a organização de grupos de ouvintes. A seção teórica ensinaria, ainda, sobre o rádio na escola primária, na escola secundária e nos cursos de extensão, o rádio e o Estado, a defesa nacional e a hora da cultura nacional. Parte dos conteúdos selecionados para o curso estão presentes em Radio e Educação $(1934)^{7}$, manual elaborado por Ariosto Espinheira com o objetivo de divulgar a radioeducação em nosso país. Os três últimos temas da parte prática do curso, não foram abordados no livro, e parecem ter sido elaborados para atingir os objetivos de socialização dos valores do Estado Novo.

O uso de cinematógrafos nas escolas criou a demanda de cursos para os professores, que deveriam operar o maquinário, conservá-lo e fazer uso pedagógico deste. Em 1943, seria ainda oferecido aos professores do Distrito Federal o Curso de Manejo, composto das partes técnica e pedagógica. A parte técnica compreendia "o estudo do filme, sua matéria prima, fabricação, formatos, no-

7 Rádio e educação foi um livro elaborado com o intuito de atender a demanda de conhecimento sobre radiofonia educativa do professorado. Sendo assim, constitui uma fonte importante para a compreensão do discurso elaborado pelos radioeducadores com o objetivo de convencer os professores acerca da importância desta modalidade de ensino. A obra é composta por cinco capítulos. Ainda na introdução, Ariosto Espinheira anuncia aos seus leitores: "O estudo que se segue representa de algum modo a somma a respostas enviadas ao Instituto Internacional de Cooperação Intelectual pelos educadores competentes bem como pelas associações de radiodifusão" (1934, p. 12). Ao longo da obra, torna-se evidente a importância deste inquérito para o autor, pois além de ser referência constante em suas citações, o quarto capítulo é composto basicamente pelos resultados da pesquisa. Tal aspecto também foi observado por Dângelo (1994) em seus estudos. A obra de Espinheira permite $o$ acesso aos dados sobre experiências realizadas na Inglaterra, Alemanha, Noruega, Suécia, Suíça, Dinamarca, México, Uruguai, Itália, Turquia, Austrália, Espanha e União Soviética, que dificilmente chegariam aos leitores brasileiros. Nesse aspecto, a circulação de tais informações é interessante. Os relatos detalhados, que incluem quadros com estatísticas do aproveitamento do curso ou a duração da programação educativa, proporcionam um contato único para seu tempo, quando não havia publicações brasileiras que tratassem especificamente da educação por meio do rádio. 
ções gerais de filmagem, trabalhos de laboratório, projeções, conhecimento dos diversos aparelhos, os cuidados essenciais para sua perfeita conservação" (A MANHÃ, 6/2/1944, p. 2). A parte pedagógica consta "da perfeita aplicação do cinema educativo, divulgação sobre as aquisições do caráter técnico, sugestões e meios que assegurem maior eficácia e produtiva das projeções animadas e fixas" (A MANHÃ, 6/2/1944, p. 2).

Há uma preocupação com a regularidade do uso do cinema educativo nas escolas. Os tópicos do programa nos dão indícios que o mestre deveria acumular as funções técnica e pedagógica. A conservação dos cinematógrafos deveria ser responsabilidade dos professores nas escolas, de forma que problemas técnicos não fossem um impeditivo para projeção regular de filmes pedagógicos. Assim como o rádio, a prefeitura dispunha de uma oficina para montagem e consertos dos aparelhos das escolas. No entanto, só se deveria solicitar o conserto depois que os professores esgotassem as possibilidades de equacionar o problema técnico em um curto prazo. Outra questão é a conservação da película: a utilização inadequada também reduziria sua vida útil. Para que o aproveitamento fosse o maior possível era necessário que os professores soubessem a maneira correta de manuseio e armazenamento.

\section{Os usos do aparelhamento moderno nas escolas}

Ao analisar os documentos é possível identificar que, para o Secretário Pio Borges, a aquisição dos receptores de rádio e de cinematógrafos deveria ser planejada a partir de um único modelo que atendesse à rede escolar. No caso do rádio, a uniformização de modelos permitiria que os cursos de formação de professores, que tinham como objetivo fomentar elementos práticos e teóricos, pudessem abordar questões técnicas de forma mais precisa, uma vez que o aparelho escolhido era bem conhecido por técnicos como João Labre Júnior, do Ministério da Educação.

Escolano Benito (2000), ao examinar o espaço escolar, identifica sua arquitetura como um programa invisível e silencioso que cumpre determinadas funções didáticas - a organização da sala de aula, por exemplo, pode ser fundamental para o desenvolvimento de determinado conteúdo ou para o trabalho com determinada técnica, indicada em manuais escolares. Tal compreensão ajuda a interpretar as determinações da equipe responsável para implantar o rádio nas escolas. Para eles, era preciso organizar a sala para a escuta, os alunos deveriam estar posicionados de acordo com a propagação do som. A organização 
em fileiras não era adequada. Uma foto registrada pela Gazeta de Notícias, em 6 de janeiro de 1942, mostra que as crianças estão posicionadas em formato de $\mathrm{V}$ com o aparelho na ponta. As carteiras coladas umas às outras, de forma que a distância do receptor seja a menor possível. O rádio em móvel alto que podia ser visualizado por todos os alunos também colaborava para o entendimento da metodologia de ensino, à medida que despertava o interesse e a curiosidade pelo artefato.

A sincronia era outra característica relevante para o uso do cinema e do rádio na escola. Os programas de rádio irradiados pela PRD5, definidos pela direção da emissora e de audição obrigatória nas escolas, estabeleciam uma mudança na rotina escolar e nos currículos de todas as escolas da rede. Com horários e temas definidos pelas emissoras, obrigava que os professores reorganizassem sua rotina, para que na hora determinada, os alunos estivessem posicionados adequadamente, com o rádio ligado e sintonizado. Na Rádio Escola Municipal, a programação da manhã se repetia à tarde para contemplar alunos dos dois turnos. Todo processo demandava um tempo considerável, que extrapolava a audição que durava de 20 a 30 minutos. $\mathrm{O}$ tempo do rádio deveria ser priorizado em relação ao cotidiano escolar, que deveria se adaptar a este. A organização dos conteúdos também era afetada pela programação imposta por Pio Borges. O Programa Nacionalista, irradiado diariamente nas escolas, transmitia propaganda das realizações do governo. Para comprovar que os programas eram ouvidos pelos alunos, estes deveriam enviar cartas para a Rádio Escola Municipal.

No caso do cinema, esta sincronia se relacionava a escassez de cópias dos filmes. A produção era cara e algumas fitas eram doadas pela BBC. A distribuição dos filmes nas escolas se dava por rodízio. Era importante que todos fossem adaptáveis ao mesmo aparelho. No caso, a preferência era o de $16 \mathrm{~mm}$, “por ser de fácil manejo e não ser inflamável” (A MANHÃ, 10/5/1942, p. 3). A mesma reportagem de $A$ Manhã esclarece que a filmoteca municipal possuía 509 filmes, que deveriam ser exibidos semanalmente, sendo dois instrutivos e um recreativo em 115 escolas da rede do Distrito Federal, que possuíam cinematógrafos. Os aparelhos de projeção fixa eram apenas 14. Os filmes exibidos para todos os alunos da escola tratavam os temas de forma única, independente dos planejamentos das séries e dos níveis de entendimento, os professores deveriam adaptar os conteúdos ministrados em suas salas.

A estrutura elétrica fundamental para exibição dos filmes e irradiação dos programas era precária. A marchinha carnavalesca Vagalume, composta em 1954 por Vitor Simon e Fernando Martins, expõe um problema do cotidiano carioca, que é presente nas manchetes dos jornais dos anos 1930 e 1940: a falta de luz. Não raro as escolas tinham que equacionar os problemas gerados pela precária 
rede elétrica. Para a radioeducação, gerava a descontinuidade das lições. No caso de um programa em sequência, era possível que o entendimento fosse muito prejudicado pela falta de regularidade das audições. Era possível que a turma toda se organizasse, e a queda de energia impedisse a irradiação. O cinema também sofria com a mesma desestrutura, mas poderia haver a reorganização das exibições, sem prejuízo do entendimento.

Nas escolas ficou determinado que deveria haver um professor responsável pela radiofonia e pela cinematografia. Este mestre teria como atribuições a guarda do aparelho, a sua conservação, sua manutenção. Esta era uma forma de concentrar os assuntos ligados ao aparelhamento escolar, que deveria multiplicar os conhecimentos adquiridos nos cursos aos demais colegas. Os cuidados deveriam garantir que o aparelho estivesse sempre disponível e, desta forma, o rádio e o cinema se integrassem definitivamente ao cotidiano escolar.

\section{Algumas considerações finais}

Todo elle, el lugar y los objetos, los espacios y las formas relacionados com la escuela, nos dice cosas de los protagonistas de la escuela del ayer, de su cultura escolar, nos informa de pasado de la escuela y sus maestros, de sus niños y família, del proyecto educativo de la sociedad del momento, de los interesses de la política educativa hegemónica (HERNANDEZ DIAZ, 2002, p. 246).

Desde o início do desenvolvimento da radiofonia e da cinematografia os educadores investiram em estudos para que estes artefatos fossem utilizados por professores em sala de aula. Durante os anos 1930, a Diretoria de Instrução Pública do Distrito Federal promoveu o uso do aparelhamento moderno nas escolas. Na administração de Anísio Teixeira houve a criação da Rádio Escola Municipal, assim como a organização de coleção de filmes escolares que incentivariam a apropriação pedagógica dos meios de comunicação, com o objetivo maior de promover a difusão da radiocultura pelo Distrito Federal e pelo país. $\mathrm{O}$ aparelhamento assume um papel complementar ao da escola, mas este processo é estabelecido com a falta dos aparelhos nas unidades escolares.

Pio Borges, responsável pela pasta de Educação durante o Estado Novo, reorganizou os serviços de cinema e radio escolares. Neste sentido, direcionou seus esforços para a compra dos equipamentos para as escolas. Os usos do 
broadcasting e da cinematografia deixam o plano das ideias e se integram ao cotidiano escolar. Este investimento tem uma relação direta com a socialização dos valores estadonovistas: o nacionalismo, o civismo e o trabalhismo.

O contexto político determinou diferentes propósitos para os usos do aparelhamento escolar nas décadas de 1930 e 1940, no entanto, as duas propostas determinaram prescrições e interdições. Compreendê-las é fundamental para estudar as práticas escolares que envolviam os meios de comunicação. Para Pio Borges, ouvir o rádio e assistir o filme na escola era muito importante, à medida que era uma ação mediada pelo professor, que faria comentários de acordo com o contexto político, evitando interpretações que fugissem aos seus propósitos. Os usos deveriam ser sincronizados, estimulando o controle do horário e do conteúdo. $\mathrm{Na}$ administração de Anísio Texeira as restrições e prescrições se concentraram mais na perspectiva da censura do conteúdo do que seria adequado para ser veiculado, tendo como horizonte a definição do que era educativo, restringindo os usos do meio de comunicação para o que era considerado diversão.

\section{REFERÊNCIAS}

A MANHÃ. Rio de Janeiro, 16/4/1941, p. 6.

A MANHÃ. Rio de Janeiro, 10/5/1942, p. 3.

A MANHÃ. AS ATIVIDADES DO CINEMA ESCOLAR DA PREFEITURA. Rio de Janeiro, 6/2/1944, p. 3.

A MANHÃ. AS ATIVIDADES DO SERVIÇO DE DIVULGAÇÃO DA SECRETARIA DE EDUCAÇÃO E CULTURA. Rio de janeiro, 20/5/1942, p. 3.

A NOITE. CURSO DE RADIOFONIA ESCOLAR. Rio de Janeiro, 29/08/1941, p. 2. A NOITE. SEMANA DA PÁTRIA E A RÁDIO ESCOLA. Rio de Janeiro, 2/9/1941, p. 5. ATA DE REUNIÃO ABE. Associação Brasileira de Educação, 1926.

AZEVEDO, Fernando. A transmissão da cultura. São Paulo: Melhoramentos, 1976.

BOLETIM DA ABE. Boletim da Associação Brasileira de Educação (ABE), Anno I, $\mathrm{n}^{\circ} 1$, p. 7, setembro de 1925 .

BOMENY, Helena. Três decretos e um ministério: a propósito da educação no Estado Novo. In: PANDOLFI, Dulce (Org.). Repensando o Estado Novo. Rio de Janeiro: Ed. Fundação Getúlio Vargas, 1999. 
BRASIL. Decreto 21.111 , de $1^{\circ}$. de março de 1932. Aprova o regulamento para a execução dos serviços de radiocomunicação no território nacional. Diário Oficial da União - Seção 1 - 4/3/1932.

CARVALHO, Marta. Molde nacional e fôrma cívica: higiene, moral e trabalho. Bragança Paulista, EDUSF, 1998.

COELHO, Patrícia e PAULILO, André Luiz. Arautos do improvável, pioneiros da radiofonia e da cinematografia educacional no Brasil (1920-1930). Educação em Revista, 31(2), 2015, pp. 37-59, 2015. Disponível em: http://www.scielo.br/pdf/edur/ v31n2/0102-4698-edur-31-02-00037.pdf. Acesso em: 23 abr. 2019.

COELHO, Patrícia. Educadores no rádio: programas para ouvir e aprender (19351950). Rio de Janeiro: PUC-Rio; Mauad, 2016.

COLLETE. DIÁRIO DE NOTÍCIAS. Rio de Janeiro, 8/3/1931, p. 7.

DÂNGELO, Newton. Escola sem professores: o rádio educativo nas décadas de 1920/1940. 1994. 225p. Tese (Doutorado) - Pontifícia Universidade Católica de São Paulo. São Paulo.

DIÁRIO DE NOTÍCIAS. Rio de Janeiro, 11/10/1930, p. 4.

DIÁRIO DE NOTÍCIAS. Rio de Janeiro 13/07/1930, p. 5.

DIÁRIO DE NOTÍCIAS. Rio de Janeiro, 23/10/1930, p. 6.

DIÁRIO DE NOTÍCIAS. Rio de Janeiro, 13/11/1930, p. 14.

DISTRITO FEDERAL. Decreto $n^{\circ} 2.940$, de 22 de novembro de 1928, do Regulamento do Ensino. Prefeitura do Distrito Federal, Rio de Janeiro, Oficinas Gráficas do Jornal do Brasil, 1928.

ESCOLANO BENITO, Agustín. Tiempos y espacios para la escuela, ensayos históricos. Madrid: Biblioteca Nueva, 2000.

ESPINHEIRA, Ariosto. Rádio e educação. São Paulo, Companhia Melhoramentos, 1934.

GAZETA DE NOTÍCIAS. OITAVO ANIVERSÁRIO DA RÁDIO DIFUSORA DA PREFEITURA. Rio de Janeiro, 6/1/1942, p. 4.

GAZETA DE NOTÍCIAS. ORGANIZADOS AFINAL OS SERVIÇOS DA RADIOESCOLA NO RIO. Rio de Janeiro, 15/8/1941, p. 4.

GAZETA DE NOTÍCIAS. SEMANA DA CRIANÇA. Rio de Janeiro, 9/10/1943, p. 5.

HERNANDEZ DIAZ, José Maria. Etnografia e Historia Material de la escuela. In: ESCOLANO BENITO, Agustin e HERNANDEZ DIAZ, José Maria (Coords). La memoria y el deseo: cultura de la escuela e educación deseada. Valencia: Tirant ló Blanch, 2002. pp. 225-246. 
INGOLD, Tim. Trazendo as coisas de volta à vida: emaranhados criativos num mundo de materiais. Horizonte antropológico, Porto Alegre, v. 18, n. 37, p. 25-44, (Junho) 2012, pp. 25-44. Disponível em: http://www.scielo.br/pdf/ha/v18n37/a02v18n37.pdf. Acesso em: 23 abr. 2019

LEMME, Paschoal. Memórias (v. 2). São Paulo: Cortez, Brasília: INEP, 1988.

MIGNOT, Ana Chrystina Venancio. Baú de memórias, bastidores de histórias: o legado pioneiro de Armanda Álvaro Alberto. Bragança Paulista, EDUSF, 2002.

NEVES, Margarida de Souza. LÔBO, Yolanda Lima e MIGNOT, Ana Chrystina Venancio (Orgs). Cecilia Meireles: a poética da educação. Rio de Janeiro: Editora PUC-Rio; Loyola, 2001.

NUNES, Clarice. Anisio Teixeira: poesia da ação. Bragança Paulista, EDUSF, 2000.

O RADICAL. A POSSE DO NOVO SECRETÁRIO DE EDUCAÇÃO MUNICIPAL. Rio de Janeiro, 13/6/1939, p.3.

O RADICAL. A POSSE DO NOVO SECRETÁRIO DE EDUCAÇÃO DO DISTRITO FEDERAL. Rio de Janeiro, 20/6/1939, p. 6.

O RADICAL. Rio de Janeiro, 22/6/1939, p. 3.

O RADICAL. EXPURGO NAS BIBLIOTECAS ESCOLARES. Rio de Janeiro, 30/7/1939, p. 4.

O RADICAL. LIVROS LANÇADOS À FOGUEIRA. Rio de Janeiro, 8/10/1939, p. 6.

O RADICAL. O HOMEM QUE TEM UMA BRAZA NAS MÃOS. Rio de Janeiro, 8/3/1940, p. 2.

O RADICAL. PRIMEIRO ANO DA ADMINISTRAÇÃO DO CORONEL PIO BORGES NA SECRETARIA DE EDUCAÇÃO DA MUNICIPALIDADE. O Radical. Rio de Janeiro, 20/6/1941, p. 3.

RIBEIRO, Adriana Gomes. Vontade de educar entre a ciência e a política: a PRD5 Rádio Escola Municipal, seu contexto e sua história. 2009. Dissertação (Mestrado em Educação) -. Universidade do Estado do Rio de Janeiro: Programa de Pós-Graduação em Educação, Comunicação e Cultura em Periferias Urbanas., Rio de Janeiro, 2009.

SALGADO, Álvaro. A radiodifusão educativa no Brasil (notas). Serviço de Documentação do Ministério da Educação e Saúde. Rio de Janeiro, 1946.

SEGISMUNDO, Fernando. Venâncio, humanitário. In: VENÂNCIO FILHO, Alberto (org). Francisco Venâncio Filho: um educador brasileiro, Rio de Janeiro: Editora Nova Fronteira, 1994, pp. 198-204. 
SOUZA, Luani de Luiz. O cinematógrafo entre os olhos de Hórus e Medusa: uma memoriábilia da educação escolar brasileira (1910-1960). 2016. Tese (Doutorado em Educação) - Universidade do Estado de Santa Catarina: Programa de Pós-Graduação em Educação. Florianópolis: Tese de doutorado, 2016.

VENÂNCIO FILHO, Francisco. A educação e o seu aparelhamento moderno. Rio de Janeiro; Companhia Editora Nacional, 1941.

Texto recebido em 01 de maio de 2019. Texto aprovado em 15 de junho de 2019. 